University of Nebraska - Lincoln

DigitalCommons@University of Nebraska - Lincoln

Faculty Publications -- Department of English

English, Department of

April 1972

\title{
Lyly's Midas as an Allegory of Tyranny
}

Stephen S. Hilliard

University of Nebraska-Lincoln, shilliard1@unl.edu

Follow this and additional works at: https://digitalcommons.unl.edu/englishfacpubs

Part of the English Language and Literature Commons

Hilliard, Stephen S., "Lyly's Midas as an Allegory of Tyranny" (1972). Faculty Publications -- Department of English. 4.

https://digitalcommons.unl.edu/englishfacpubs/4

This Article is brought to you for free and open access by the English, Department of at DigitalCommons@University of Nebraska - Lincoln. It has been accepted for inclusion in Faculty Publications -- Department of English by an authorized administrator of DigitalCommons@University of Nebraska - Lincoln. 


\section{Lyly's Midas as an Allegory of Tyranny*}

\section{Stephen S. Hilliard}

John Lyly's Midas is structured in terms of traditional allegorizations of the Ovidian myth that represent Midas as an avaricious and ignorant tyrant. Lyly is thus concerned with a theme popular in the public theater, but he treats it in allegorical manner distinctive in its focus on theme rather than character or action. The play first portrays Midas's mistaken choice of a private end, the accumulation of wealth for its own sake and as a means of financing lechery and aggression, then suggests the difficulties this causes in the governing of his kingdom. The episode in which Midas judges the singing contest of Pan and Apollo is not unrelated; rather it contributes to the thematic development by depicting allegorically the ignorance of the divine order which caused Midas's tyranny. In the last act the repentant king submits to the divine order in a scene of Lyly's invention that underscores the allegorical theme.

$\mathrm{T}$ he graceful wit of John Lyly's plays was for many years probed only by an occasional scholar in search of political allusions; to the general critic they remained little more than skillful comedies of manners. G. K. Hunter has begun a revaluation of Lyly that should establish him as a writer in the

" Published in Studies in English Literature, 1500-1900, Vol. 12, No. 2, Elizabethan and Jacobean Drama. (Spring, 1972), pp. 243-258.

Copyright 1972 William Marsh Rice University. Used by permission. grand tradition of Renaissance humanism, but his study, for all its historical insight, did not demonstrate the thematic complexity that enriches Lyly's plays. ${ }^{1}$ This article is intended to show that Lyly treated in his play Midas the nature of tyranny, a theme usually associated with the public theater. His use of allegory in depicting this theme is an informative example of the Elizabethan use of the allegorical mode for dramatic purposes. Midas is perhaps "a model of elegant speech and a mirror of manners," to use M. C. Bradbrook's terms, but Lyly is deprived of his due as an artist if the analysis of his plays is restricted to the surface. ${ }^{2}$

In his prologue Lyly himself seems to disavow any central purpose in his play :

At our exercises, Souldiers call for Tragedies, their obiect is bloud: Courtiers for Commedies, their subiect is loue: Countriemen for Pastoralles, Shepheards are their Saintes. Trafficke and trauell hath wouen the nature of all Nations into ours, and made this land like Arras, full of deuise, which was Broade-cloth, full of workemanshippe.

Time hath confounded our mindes, our mindes the matter, but all commeth to this passe, that what heretofore hath beene serued in seuerall dishes for a feaste, is now minced in a charger for a Gallimaufrey. If wee present a mingle-mangle, our fault is to be excused, because the whole worlde is become an Hodgepodge. $^{3}$

M. C. Bradbrook uses sentences from this prologue as evidence for her thesis that Lyly's only purpose was to please. "Lyly is not striving to impose a meaning, but invites a variety of interpretation. The plays signify 'what you will' and should be taken 'as 
you like it'. The audience's demands, however various, will all be met." ${ }^{4}$ But surely this is to take this prologue too literally-we need only ask ourselves how many countrymen attended performances at the private theater where the play was performed. In context this apparent self-deprecation is part of the play's mild satire on society, since the blame is placed on the audience. The play itself, as we shall see, belies the claim that Lyly intended to please indiscriminately: neither the soldier, the courtier, nor the countryman will find his imputed taste for drama satisfied. They will be entertained, but it will be on Lyly's terms, not their own.

Midas seems a "mingle-mangle" to us because of the apparent lack of connection between its two major episodes, the stories of Midas's golden touch and of his acquisition of ass's ears, but the original audience saw them as having a common theme. Both episodes were well known to the Elizabethans through Ovid's Metamorphoses and were thought to convey moral allegory. The traditional allegorizations were disseminated through glosses on Ovid and became widely known, as can be seen in the number of casual allusions to the Midas myth in popular works of the period. The interpretation offered by Arthur Golding in the epistle he prefixed to his translation of the Metamorphoses represents the Elizabethan understanding of the myth in its simplest and probably most widespread form :

In Midas of a couetous wretch the image wee may see Whose riches iustly too himself a hellish torment bee,

And of a foole whom neyther proof nor warning can amend,

Untill he feele the shame and smart that folly doth him send. ${ }^{5}$

For us the allegorization of the first episode seems more natural; perhaps it is because of this naturalism that the story of Midas's golden touch remains a popular children's story. But the second episode was as familiar to the Elizabethans as the first and its allegorization so well known that it obtained the currency of a commonplace. We can only sample here the number of references to his obtuse preference for the music of Pan and the shameful punishment accorded him by Apollo. Nashe in a discussion of bad poetry reminds his readers that they "haue seene Pan sitting in his bower of delights, \& a number of Midasses to admire his miserable hornepipes." ${ }^{\prime 6}$ Marlowe in Hero and Leander laments that in this corrupt age "Midas brood shall sit in Honors chaire," and Lodge in Rosalynde belittles "any squinteied asse, that hath mighty ears to conceiue with Midas, and yet little reason to iudge." 7 Abraham Fraunce is more specific about the nature of his stupidity: "Mydas the golden asse, and miserlike foole ... prefered Pans rurall harmony before the heauenly skill of Apollo....." 8

In addition to the idea derived from Ovid that Midas was covetous and a fool, there existed another tradition, perhaps euhemeristic in origin, that Midas was a tyrant. In The Dial of Princes, for example, we are told that Midas "was in his gouernment a cruell tyrant, and contented not him self to play the tiraunt in his own proper countrey, but also mainteined rouers on the sea, and theeues in the land to robbe straungers." ${ }^{9}$ Erasmus referred to Midas as one of those tyrants "whose names are now objects of hate to all the human race." ${ }^{10} \mathrm{He}$ contrasted Midas with Solomon, who was also given a wish and chose wisdom to rule his kingdom: "Just the opposite is true of Midas, who is condemned by everyone because nothing was more precious to him than gold." ${ }^{11}$ Behind this comparison with Solomon lay a Renaissance commonplace that a tyrant was a king who desired a private end rather than a public good. Typically, "reward to a tyrant is wealth; to a king honor, which follows upon virtue," as Erasmus put it. ${ }^{12}$ Midas is, then, an apt example of a 
tyrant, for his avarice represents admirably the private desire for wealth which was particularly likely to pervert a king from his true office.

Midas is a tyrant because he is avaricious, but more basically he is avaricious because he is ignorant-the antithesis of Solomon. This connection is made in an allegorized edition of Ovid's tales published at Cambridge in 1584:

Ergo non dubium est hanc fabulam esse confictam in principes auaros \& indoctos, quibus pluris est aurum, quam sapientia : infantia quam eloquentia: barbaries quam eruditio. neque aliud sunt aures asininae, quae Midae affinguntur, nisi aures ineruditae: tametsi earundem allegoria possit etiam ad alia referri. $^{13}$

The gloss George Sandys appended to his translation of the Metamorphoses develops this interpretation of the second episode for us. It is not merely parallel to the first episode, but a thematic elaboration which exposes the cause of Midas's mistaken desire for riches. "His conversation with Pan, denotes the bruitish and ignorant life, which he led: cleansed from covetousnesse, but retaining his folly." Sandys sums up the traditional allegorization: "Pan presents illiterate rusticity; Apollo a minde imbued with the divine endowments of art and nature. Midas an ignorant Prince, unable to distinguish betweene that which is vile and excellent; and therefore preferres the one before the other; for which he is justly branded by the learned with the ensignes of folly." ${ }^{14}$ It is from this kind of understanding of the significance of the myth that Lyly developed his play.

Treating the nature of tyranny in a play was, of course, no innovation on Lyly's part: during the Elizabethan period the public theater frequently dramatized the subject in plays like Damon and Pithias or Cambises. ${ }^{15}$ Non-dramatic literature and political tracts also witness the contemporary popularity of the subject. In the years immediately following the defeat of the Armada it gained added interest because of the supposed tyranny of Philip II of Spain. Lyly's allusions in Midas to Philip have led many modern readers of the play to the conclusion that Midas represents the Spanish king throughout the play. ${ }^{16}$ Certainly lines such as the following link Midas to Philip: "Haue not I made the sea to groane vnder the number of my ships: and haue they not perished, that there was not two left to make a number?" $\left(\mathrm{C}^{\mathrm{r}}\right)$ The golden touch and references to the mines of Midas suggest topical allegory, as do his foreign wars and attempts to undermine neighboring states by financing sedition. However, there would surely be many more such allusions if Lyly's primary intent was topical allegory. Instead Lyly's allegory only refers occasionally to Philip-Philip is an example of the tyranny that is Lyly's allegorical subject, much as Elizabeth is an example of the chastity figured forth by Belphoebe in The Faerie Queene. Midas is more intelligible if it is seen as a straightforward anatomy of tyranny than as a dark conceit of Philip's aggression.

From the first the emphasis in the play is on Midas as a king, for he responds to the offer by Bacchus of anything he wishes by asking advice of his counselors in proper regal fashion: "Now my Lords, let me heare your opinions, what wish may make Mydas most happie and his Subiects best content?" $\left(\mathrm{A} 1^{\mathrm{r}}\right)$ In seeking advice and identifying his happiness with the well-being of his subjects Midas seems an ideal ruler, but the remainder of the first scene establishes that his concern for his people is hypocrisy and his request for counsel meaningless, since his counselors are corrupt. A contemporary tract on the duties of royal counselors mentioned that "As euerie man is by speech discouered, So a Counsellor by vttering his opinion declareth how 
wise and prudent he ought be accounted.. ${ }^{17}$ In their debate the counselors of Midas blatantly plead for selfish ends rather than the common good. Most obviously spurious are the arguments of Eristus that Midas seek success in love; his courtly language does not conceal that love for him is the satisfaction of lust. The advice of the second lord, the "war hawk" Martius, that Midas should, Tamburlaine-like, seek to rule the world is also contrary to the doctrine of sound kingship. As Erasmus had written, "A good prince should never go to war at all unless, after trying every other means, he cannot possibly avoid it." ${ }^{18}$ Martius reveals the rigid logic and inability to make logical distinctions still sometimes attributed to the military mind: "Those that call conquerors ambitious, are like those that tearme thrift couetousnes, clenlines pride, honestie precisenes" $\left(\mathrm{A}^{\mathrm{v}}\right)$. Midas later characterizes this kind of thinking when he tells Martius, "Thou wouldst quench fire with a sword" $\left(\mathrm{G} 3^{\mathrm{r}}\right)$.

Midas accepts the counsel of the third lord, Mellacrites, because he argues that Midas can gratify his lust and gain dominion by asking that all he touches turn to gold. His long speech offers wrong motives for desiring wealth: "Is it not gold that maketh the chastest to yeeld to lust, the honestest to lewdnes, the wisest to follie, the faithfulest to deceit, and the most holy in heart to be most hollow of hart?" $\left(\mathrm{A} 1^{\mathrm{v}}\right)$ The irony of Mellacrites's apotheosis of gold is obvious in his emblematic interpretation of "Justice": "Iustice her selfe, that sitteth wimpled about the eyes, doth it not because shee will take no gold, but that she would not be seene blushing when she takes it: the ballance she holdeth are not to weie the right of the cause, but the weight of the bribe: she wil put vp her naked sword if thou offer her a golden scabberd" $\left(\mathrm{A} 2^{\mathrm{v}}\right)$. Thus the cupidity Midas evidences in wishing for the golden touch is not simple avarice, but a combination of the goals advised by his three lords and of his own presumption: "I wil comaund bothe the affections of men, and the fortunes. . . Thus shal Mydas be monarch of the world, the darer of fortune, the commander of loue" $\left(\mathrm{A}^{\mathrm{r}}\right)$. His overweening pride is also emphasized in his scorn at the parting words of Bacchus, "Poenam pro munere poscis" $\left(\mathrm{A}^{\mathrm{r}}\right)$, "you ask a punishment as a reward." These are the words spoken to Phaethon in Ovid, so they perhaps reminded the audience that Phaethon was also allegorized as an ambitious ruler who forgot his place in the scheme of things. ${ }^{19}$ Midas's dismissal of this warning, "Now it is done, I care not for anything he can doe" $\left(\mathrm{A} 3^{\mathrm{r}}\right)$, fixes him in the mind of the audience as a scorner of the gods, likely to suffer retribution.

In the first scene, then, Lyly has begun his anatomy of tyranny, but not by means of an analysis of the "character" of Midas. There is, for example, little interest in the effect of the set speeches of the three lords on Midas, rather they are directed at the audience, who doubtless enjoyed seeing through the patent weaknesses of the arguments. The "hero" Midas has spoken less than fifty lines and does not appear again on stage until the third act. The effect of his golden touch is so well known that it is sufficient to introduce news of it as court gossip in the subplot at the end of the first act. Because Lyly's interest is in the allegorical significance of the myth, not simply in staging it vividly, he passes over the comic possibilities of depicting Midas's plight. Instead he continues the debate between the three lords, but now in the presence of Sophronia, the daughter of Midas, invented by Lyly to express the wisdom her father lacks.

This review of the arguments of the three counselors at the beginning of the second act, after Midas's wish has proved unfortunate, establishes that he has been guilty of the vices of all three counselors. Besides amassing wealth, he has attempted to purchase the chastity of Caelia and has embroiled his country in foreign wars. The corruption in Phrygia is not limited to its king: 
Martius complains that Midas's insatiable thirst for gold and his beastly lust, "coloured with courtlie name of loue," have permeated and subverted the court $\left(\mathrm{B}^{\mathrm{v}}\right)$. This is in accord with Elizabethan political belief: "rather from the life of Princes, doe subiects take their paterne and examples, then from their lawes." ${ }^{20}$ This theory that a king is an ethical example for his subjects serves to relate the subplot to the main action, for the intrigues of the pages can be said to imitate the corruptions of the court, particularly when they conspire to obtain the golden beard Motto has shaved from the king. It is for this reason that Sophronia's criticism of the three lords is concerned with their effect on the country as much as on her father: "Let Phrygia be an example of chastitie, not luste; liberalitie, not couetousnes; valor, not tyrannie. I wish not your bodies banisht, but your mindes, that my father and your king, may be our honor, and the worlds wonder" $\left(\mathrm{B} 3^{\mathrm{v}}\right)$.

The long set speech of Midas as he undertakes his cure, bathing in the river Pactolus, stresses his awareness of his failings as a king. Such self-pity was to be expected of a tyrant, for "to saie truth, tyrannie is such a miserable condition, that even they that practice it and glorie therein, are constrained manie times to confesse with their owne mouth that no kinde of life is so wretched as theirs." ${ }^{21}$ In bemoaning his fate Midas sums up his mistakes : "I finde neither mercies in my conquests, nor colour for my warres, nor measure in my taxes. I haue written my lawes in blood, and made my Gods of golde" $\left(\mathrm{C} 2^{\mathrm{r}}\right)$. Allusions to excessive taxes here and later by the restive "commons" made up of five shepherds may seem unrelated to any action in the play, but they are easily understandable as a predictable aspect of Midas's tyranny. Midas continues by contrasting his corrupt rule of Phrygia with the beneficent rule of the king of Lesbos over his realm. Some who have argued that Midas represents
Philip II have claimed that Lesbos represents England; however, if Lyly's major purpose was topical allegory he could easily have made his sovereign of Lesbos a queen with some of the specific attributes usually praised in Elizabeth. Instead it is a king figuring forth the royal virtues advocated by contemporary political theorists without any details that would suggest allusions to the contemporary situation. In this respect Lyly's king of Lesbos is like Euarchus, the model king of Sidney's Arcadia, and conversely Midas is similar to Sidney's nameless king, also of Phrygia, who was a melancholy, suspicious, and greedy tyrant. ${ }^{22}$ This good king of Lesbos is "a Prince protected by the Gods, by Nature, by his own vertue, and his Subiects obedience." Moreover, asks Midas, "Is hee not through the whole world a wonder, for wisdome and temperance?" ( $\left.\mathrm{C}^{\mathrm{v}}\right)$ Midas is by his own admission a "shame to the world."

The thought of this model prince goads Midas into seeking to reform himself: "I will to the riuer, where if I be rid of this intollerable disease of gold, I will next shake off that vntemperat desire of gouernment, and measure my Territories, not by the greatnesse of my minde, but the right of my Succession" $\left(\mathrm{C}^{\mathrm{v}}\right)$. But instead of reforming he continues in the second half of the play to war against Lesbos and practice tyranny at home. The "commons" of five shepherds tell us later in the play that Midas is still the opposite of the king of Lesbos: "(though we dare not so much as mutter it,) their king is such a one as dazeleth the cleerest eyes with Maiestie, daunteth the valiantest hearts with courage, and for vertue filleth all the world with wonder" $\left(\mathrm{B}^{\mathrm{r}}{ }^{\mathrm{r}}\right.$ $\left.B 3^{\mathrm{v}}\right)$. Lesbos remains the antithesis of Midas's corrupt kingdom, a continuing example of what his reign should be.

It is after the third act, when Midas has been cured of his golden touch, that readers are apt to see a break in the structure of the play, since the fourth act opens with the singing contest of 
Pan and Apollo. To the extent that our interest centers on the action, there is an obvious break, but the original audience, as we have seen, saw the first three acts as debates on tyranny and portrayals of its results rather than as a simple retelling of the Ovidian myths. The elements of Lyly's art-the rhetorical set pieces, the debates, the juxtapositions of contrasting characters and events-have been used to present a comic anatomy of tyranny, which now continues in the singing contest of the gods. The contest is staged as a dramatic emblem, illustrating Midas's relationship to ultimate values. In this case the scene is almost literally a staged emblem, for the motif had been used a few years earlier by Geffrey Whitney in his A Choice of Emblems (1585). The contest of Pan and Apollo is depicted under the heading Peruersa iudicia and its moral applied:

PRESUMTVOVS PAN, did strive APOLLOS skill to passe:

But MIDAS gaue the palme to PAN; wherefore the eares of asse

APOLLO gaue the Iudge: which doth all Iudges teache;

To iudge with knowledge, and advise, in matters paste their reache? ${ }^{23}$

This emblem, like the glosses to Ovid and proverbial allusions to Midas's punishment cited earlier, indicates that Lyly's audience knew the general significance of the contest episode and could anticipate how Lyly would relate it to the tyranny of Midas.

The dialogue between the two gods before Midas happens on the scene establishes the superiority of Apollo over the arrogant Pan, unless we are blinded by our taste for the rustic. Apollo cites the classical examples of Orpheus, Arion, and Amphion in support of his claim that he "tunes the heauens, and makes them all hang by harmony" (D3 ${ }^{\mathrm{v}}$ ) In contrast, Pan's claims are earthly and linked to lust: "Loue made Iupiter a goose, and Neptune a swine, and both for loue of an earthlie mistresse" (D4 $\left.{ }^{\mathrm{v}}\right)$. In fact Jupiter became a swan and Neptune was never a swine: Pan's barnyard mind emphasizes the significance of these allusions, for, as Adlington wrote in his dedication to The Golden Asse: "Verily under the wrap of this transformation is taxed the life of mortall men, when as we suffer our mindes so to bee drowned in sensuall lusts of the flesh, and the beastly pleasures thereof ... that we lose wholly the use of reason \& vertue, which properly should be in man, and play the parts of brute and savage beasts." ${ }^{24}$ Pan's view of life is earthly and unregenerate, while that of Apollo is Neoplatonic in its implications and related to the idea of a celestial order. ${ }^{25}$

Their two songs, which Midas is asked to judge, differ little in the quality of their verse, but the subjects make clear the error of his choice. Apollo's song is a blazon on Daphne's beauties with Neoplatonic overtones: "My Daphne's voice tunes all the Spheres, My Daphne's Musick charmes all Eares." ${ }^{26}$ Pan's song in praise of Syrinx is more a country jig, unadorned and rustic in its language: "Pan's Syrinx was a Girle indeed, Though now shee's turn'd into a Reed." ${ }^{27}$ In performance the boy playing Pan probably sang off-key, accentuating the difference between the two songs and adding to the comedy of the scene. In this way the nymphs would be correct in their preference for the harmonies of Apollo over the piping of Pan, which they describe as keeping neither measure nor tune. Midas disagrees, "I brooke not that nice tickling of strings, that contents mee that makes one start" $\left(E 1^{\mathrm{v}}\right)$. His preference for the raucous, earthly music of Pan makes the infliction on him of beast's ears appropriate. As soon as he is left to himself he acknowledges that he is the dullest of beasts for "preferring the barbarous noyse of Pans pipe, before the sweete melolodie of Apolloes lute" and compares his present 
humiliation with his earlier mistaken wish: "Vnfortunat in thy wish, vnwise in thy iudgment; first a golden foole, now a leaden asse" $\left(E 2^{\mathrm{r}}\right)$. In concluding this long speech he touches on the political implications of his folly: "Ah foolish Mydas, a iust reward, for thy pride to wexe poor, for thy ouerweening to wexe dull, for thy ambition to wexe humble, for thy crueltie to say, Sisque, miser semper, nec sis miserabilis ulli" (E2 $\left.{ }^{\mathrm{r}}-\mathrm{E}^{\mathrm{v}}{ }^{\mathrm{v}}\right)$.

The remainder of the fourth act is concerned with a third element of the Midas story not previously mentioned: his efforts to keep his ass's ears concealed, and the subsequent disclosure of his secret by whispering reeds. In Lyly's version the nymphs have sung of Midas's punishment and been overheard by shepherds, who grumble about his tyranny among the retentive reeds. Midas's barber is deprived of the importance he enjoyed in Ovid as the discloser of Midas's secret, and is relegated by Lyly to the subplot. The pages cozen him into blurting out the truth, but in so doing he only mirrors the more significant disclosure in the main plot. Probably Lyly changed the myth in this way because he wished to emphasize the allegorization of the episode, which was that the truth about a king's misrule cannot be kept secret. Erasmus asked, "Who was ever so formidable a tyrant that he could check the tongues of everyone?"28 The seditious talk of the shepherds is precisely the sort of treason Midas wishes to suppress. They complain that, since Midas has blurred "his diademe with blood, which should glister with nothing but pittie," and "made gold his god, that was framde to be his slaue, manie broad speeches haue flowen abroad: in his owne Countrey they stick not to call him Tyrant, and else where vsurper" $\left(E 2^{\mathrm{v}}\right)$. The whispering of the reeds represents the rumors he cannot suppress, as Midas realizes when he hears them: "Sophronia, thou seest I am become a shame to the world and a wonder" $\left(\mathrm{F} 2^{\mathrm{v}}\right){ }^{29}$
The redemption of Midas is an innovation by Lyly that serves to evoke the divine order, the ignorance of which caused Midas to be a tyrant. Midas's submission to a higher power has been prepared for since the first scene, in which, as we saw, he scorned the gods while seeking to become god-like himself. Mellacrites told him: "In this word Gold are all the powers of the gods, the desires of men, the woonders of the worlde, the miracles of nature, the losenes of fortune and triumphs of time" $\left(\mathrm{A} 1^{\mathrm{V}}\right)$. Midas suffers because of his decision to pursue power, but his suffering is not contrition, for he persists in his campaign against Lesbos. Sophronia, aware of this, says in II, i: "I would the Gods would remoue this punishment, so that Mydas would be penitent" $\left(\mathrm{B}^{\mathrm{v}}\right)$ When the spreading corruption of his kingdom and the reputation he is acquiring as a tyrant become clear to him, he is finally humbled into sincere repentance. At the beginning of the fifth act Sophronia explains to him: "The Gods dally with men, kings are no more: they disgrace kings, lest they shuld be thoght gods ... (F2 $\left.{ }^{\mathrm{v}}\right)$. Realizing her words are true, Midas resolves to submit himself to Apollo and offer sacrifice: "I will to Apollo, whose Oracle must be my doome, and I fear me, my dishonor, because my doom was his, if kings may disgrace gods: and gods they disgrace, when they forget their dueties" $\left(\mathrm{F}^{\mathrm{r}}\right)^{\mathrm{r}}$. Midas is learning that kings may be like gods on earth, but they are still men to the gods. La Primaudaye said of the Prince: "Let him be perswaded that dignitie, greatnes and majestie are not to be sought after by the helpe of fortune, or by humane meanes, but by wisedome, integretie of life and mannners, and by vertuous and noble deeds." ${ }^{30}$ As the sun in heaven resembles the divinity of God, "so a prince is the like representation and light in a kingdome, as long as he hath the feare of God, and the observation of justice imprinted in him.",31 
Scenes of pagan ritual are common in Elizabethan mythological plays: the Fates offer obeisance to Elizabeth at the end of Peele's Arraignment of Paris; the shepherds to Neptune in Lyly's Gallathea; and the nymphs to Ceres, and Ceres and the foresters to Cupid, in his Loves Metamorphosis. In each case there is no evidence of antiquarian interest in actual pagan ritual; rather each establishes allegorically the relation between one embodied concept and another. Similarly, Midas's homage to Apollo is not a representation of pagan religion, but an allegorical depiction of the relationship of a king to divinity. First Midas rejects the doubts of Martius, in so doing repudiating his counselors: "Thou art barbrous not valiant. Gods must bee entreated not commanded: thou wouldst . . . ad to my shame (which is more than any Prince can endure) thy rudeness, (which is more than any sensible creature would follow)" (G3 $\left.{ }^{r}\right)$. His interpretation of the oracle makes clear what the audience had by now deduced from the action :

My pride the gods disdaine; my pollicie men: my mines haue bin emptied by souldiers, my souldiers spoyled by warres, my wars without successe, because vsurping, my vsurping without end, because my ambition aboue measure. I wil therfore yeeld my self to Bacchus, and acknowledge my wish to be vanitie. to Apollo, and confesse my iudgement to be foolish: to Mars, and say my warres are vniust: to Diana, and tell my affection hath been vunnaturall. And I doubt not, what a God hath done to make me know my selfe, al the gods wil help to vndo, that I may come to my selfe.

Midas knows himself in part because he knows his vices, but also because he is now aware that he is restricted in his actions and wishes by the hierarchy in which he is a part. Since selfknowledge has led Midas to sincere repentance, Apollo accepts his submission and offers him counsel, "which if thou scorne, thou shalt finde thy destinie" $\left(\mathrm{G} 4^{\mathrm{r}}\right)$. The words of the oracle are a riddle to all except Midas and the audience:

Weigh not in one ballance gold and iustice.

With one hand wage not war and peace.

Let thy head be glad of one Crowne.... (G4 $\left.{ }^{\mathrm{r}}\right)$

Midas promises to cease coveting Lesbos and bring his life into accord with the divine order represented by Apollo: "Sacred Appollo; if sacrifice yerely at thy temple, and submission hourely in mine owne Court, if fulfilling thy Counsell, and correcting my councellors, may shake off these Asses eares, I heere before thee vow to shake off all enuies abrode, and at home all tyrannie" $\left(G 4^{\mathrm{v}}\right)$. However, the emphasis here, as earlier in the play, is not on Midas as an individual character; Lyly has not added this conversion of Midas simply as a comic ending, but as a final step in his analysis of tyranny. The final resolution of Midas could be said to underline the political nature of his experience, but it would be more accurate to say it sums up the experience of the audience. In his last words he focuses attention not on his own restitution, but on that of his kingdom: "Phrygia shalbe gouerned by Gods, not men, leaste the Gods make beasts of men. So my counsell of warre shal not make conquests in their owne conceiptes, nor my councellers in peace make me poor, to enrich them selues" (G4 $\left.{ }^{\mathrm{v}}\right)$.

The play's last scene is, then, an affirmation of the order that should prevail in a kingdom instead of the tyranny Midas has imposed on Phrygia. The kingdom of Lesbos, the antithesis of Phrygia as we have seen, becomes in this last scene those mythical fortunate isles that were an important part of the Elizabethan 
political mystique: "I perceive (and yet not too late) that Lesbos wil not be touched by gold, by force it cannot: that the Gods haue pitched it out of the world, as not to bee controlde by any in the world" $\left(\mathrm{G} 4^{\mathrm{r}}\right)$. If Lyly is linking Lesbos to England, it is as an ideal England should emulate, rather than as a simple surrogate. The Neoplatonic implications of this attitude towards Lesbos are reinforced by the final hymn in praise of Apollo. But, while the positive vision of the last scene is a fitting conclusion to the themes Lyly developed in the play, it is at the same time a suitable comic denouement in its portrayal of the reestablishment of order. To end as Ovid did with Midas humiliated, but forever cursed with ass's ears, would not make a very satisfactory comedy. Midas's redemption is demanded by Lyly's need for a comic resolution, but is realized in a scene that also satisfies the audience's interest in the play's thematic concerns.

The play Midas is an example of Lyly's dramatic allegory at its most effective, for in it the elements of his art serve well the entertaining allegory he is developing. The debate in the first scene is lively and witty in the best manner, but it also establishes effortlessly the thematic concerns of the play. The repartee of the subplot about court affectations and the new "golden age" of Midas is enriched with relevant thematic implications without losing its lightness and pace. Perhaps most successful of all is the singing contest between the gods, a vivid scene that makes good use of the always popular dramatic motif of the trial or contest. In it Lyly utilizes the vocal talents of his boys and probably their abilities as comic mimics in stage business such as the altercation of the two gods and in tableau effects such as the obtuse deliberations of Midas. The scene is striking and quite comic, while at the same time an effective emblem for the ignorance of divine order that caused Midas's tyranny. Similarly, the last scene makes use of pagan ritual and an oracle to emphasize the proper relationship of kingship to the divine order, but this too is staged in a lively, entertaining way that is not overtly didactic. Throughout the play Lyly's development of his allegorical theme is subtle enough to have escaped the notice of modern readers unfamiliar with the traditional allegorizations of the Midas myth or with the commonplace political theory of the period. But once the concern of the play with the nature of tyranny is recognized, it ceases to seem a "mingle-mangle" and can be enjoyed as the unified comedy that it is. The skill with which Lyly constructed this comic allegory suggests his work should be taken more seriously in the study of the development of Elizabethan drama, for the concern in his plays with entertaining through intellectual toying with ideas is perhaps more influential than we realize.

\section{Notes}

1. G. K. Hunter, John Lyly: The Humanist as Courtier (Cambridge, Mass., 1962).

2. M. C. Bradbrook, The Growth and Structure of Elizabethan Comedy (London, 1961), p.62.

3. Midas (London, 1692), sigs. $\mathrm{A} 2^{\mathrm{r}}-\mathrm{A} 2^{\mathrm{V}}$. All citations will be to this edition.

4. Growth and Structure, p. 39.

5. The XV. Bookes of P. Ouidius Naso, entytuled Metamorphosis ... (London, 1575), sigs. $\mathrm{A} 4^{\mathrm{r}}-\mathrm{A} 4^{\mathrm{V}}$.

6. Thomas Nashe, The Works, ed. Ronald B. McKerrow (Oxford, 1958), "Preface to 'Astrophel and Stella,' III, 329.

7. The Works of Christopher Marlowe, ed. C. F. Tucker Brooke (Oxford, 1910), p. 503, 1.475; Thomas Lodge, Rosalynde: Euphues Golden Legacy ... (London, 1592), sig. A3 ${ }^{\mathrm{r}}$. Lyly himself wrote 
that his Euphues "coulde easily discerne Appollos Musicke from Pan hys Pype" [Euphues, The Anatomy of Wit (London, 1579), sig. $\left.B 2^{\mathrm{r}}\right]$. This idea is commonplace enough to render improbable the allusion to Lyly's play R. Warwick Bond [The Complete Works of John Lyly (Oxford, 1902), III, 111] thought he detected in Nashe's An Almond for a Parrat (Works of Nashe, III, 341-342): "now a dayes, a man can not haue a bout with a Balletter, or write Midas habet aures asininas in great Romaine letters, but hee shall be in daunger of a further displeasure."

8. The Third part of the Countesse of Pembrokes Yuychurche (London, 1592), sig. $\mathrm{D} 1^{\mathrm{r}}$.

9. Antonio de Guevara. The Dial of Princes. .., tr. T. North (London, 1668), sig. J4 .

10. Desiderius Erasmus, The Education of a Christian Prince, tr. Lester K. Born (New York, 1936), p. 163.

11. Erasmus, p. 185.

12. Erasmus, p. 163.

13. Fabvlarum Ouidii Interpretatio, Ethica, Physica, et Historica ... (Cambridge, 1584), sigs. Dd6 ${ }^{\mathrm{r}}-\mathrm{Dd} 6^{\mathrm{V}}$.

14. Metamorphoses (London, 1640), pp. 212-213.

15. W. A. Armstrong, "The Elizabethan Conception of the Tyrant," Review of English Studies, XXII (1946), 161-81.

16. Albert Feuillerat, John Lyly: Contribution à L'Histoire de la Renaissance en Angleterre (Cambridge, 1910), pp. 197-210; Lyly, Works, ed. Bond, III, 108-110; Hunter, Lyly, pp. 180-81.

17. Laurentius Grimaldus Goslicius, The Covnsellor ... (London, 1598), sig. I6 ${ }^{\mathrm{v}}$.

18. Erasmus, p. 249.
19. Phaethon is allegorized in this way in, for example, the influential mythological handbook of Natalis Comes, Natalis Comitis Mythologiae . . (Frankfurt, 1596), sigs. M6 ${ }^{\mathrm{v}}-\mathrm{M7}^{\mathrm{r}}$.

20. Matthieu Coignet, Politique Discourses vpon Truth and Lying, tr.E. Hoby (London, 1686), sig. G4 .

21. "Pierre de La Primaudaye, The French Academie (London, 1594), p. 626.

22. Sir Philip Sidney, The Prose Works, ed. Albert Feuillerat (Cambridge, 1912), vol. I: Euarchus is characterized in Bk. II, Ch. 6, pp. 184-187; the king of Phrygia in Bk. II, Ch. 8, pp. 196-197.

23. A Choice of Emblems and Other Devises (Leyden, 1586), sig. $\mathrm{C} 1^{\mathrm{v}}$.

24. The Golden Ass of Apuleius, tr. William Adlington, intr. Charles Whibley (London : The Tudor Translations, 1893), p. 8.

25. Apollo was, of course, an important figure for the Neoplatonists - see, for example, Frances A. Yates, The French Academies of the Sixteenth Century (London, 1947), pp. $84 \mathrm{ff}$.

26 . The songs were not printed in the quarto, but are in Lyly's Sixe Covrt Comedies (London, 1632), $\mathrm{X} 6^{\mathrm{r}}-\mathrm{X} 6^{\mathrm{V}}$.

27. The several references to Pan's love for Syrinx might well be relevant to the audience. See Fraunce, Yuychurches, sig. D1: "Syrinx runs from Pan: soe doth immutable constancy foresake these inferior matters, which are daily tossed to and fro, and continually subiect to ten-thousand alterations."

28. Erasmus, p. 190.

29. The idea is traditional: e.g. Comes, sig. Ss $3^{\mathrm{r}}$.

30. French Academie, pp. 609-610.

31. French Academie, p. 611. 